\title{
Ecologically sustainable integrated weed management in dry and irrigated direct-seeded rice
}

\begin{abstract}
Weeds are one of the major biological constraints in direct seeded rice farmer's field and cause a substantial rice yield loss owing to greater diversity in weed flora due to alternate wetting and drying. Sometimes more than three flushes of weed infest the direct seeded rice (DSR) in whole life cycle of crop. In India, weeds are mainly controlled manually in rice. However, manual weeding is becoming less cost effective because of labour crisis at critical times or increased labour costs. Herbicides are replacing manual weeding at a faster rate in rice as they are easy to use but there are concerns about the sole and repeated use of herbicides, such as evolution of resistance in weeds, shifts in weed flora, cost of weed management to farmers and concerns about the environment. Therefore, there is an urgent need to effectively integrate different aspects of ecological weed management strategies especially preventive measures like stale seedbed technique, summer tillage, precession land leveling, crop rotation and sowing methods, cultural methods like competitive varieties, herbicide resistance varieties, seed rate, crop residues/straw mulching, cover crops and live mulching, brown manuring, water and nutrient management (specially organic amendments), manual and mechanical method, bio-control agent to achieve effective and sustainable weed control in DSR systems. This paper describes different approaches, including preventive, cultural approaches, mechanical approach and biological approach to manage weeds in dry seeded rice as well as irrigated DSR culture systems.
\end{abstract}

Keywords: direct seeded rice, ecological weed management, cover crops and live mulches
Volume 8 Issue 4 - 2018

\author{
Mona Nagargade, MK Singh,V Tyagi \\ Department of Agronomy, Banaras Hindu University, India
}

Correspondence: MK Singh, Department of Agronomy, Institute of Agricultural Sciences, Banaras Hindu University, Varanasi -221005, Uttar Pradesh, India,

Email mksingh194.m@gmail.com

Received: June 17,2017 | Published: August 01, 2018

\section{Introduction}

Rice is considered one of the most important staple foods in the world as it supplies the major food requirement for more than one half of the world's population. Traditionally, rice is grown by raising rice nursery and transplanting one month old nursery seedlings in a puddle and flooded field. ${ }^{1}$ This method not only effectively suppresses the rice weeds by preventing the light to reach the weeds through a layer of the standing water and also provides the rice plants with a better growing environment. ${ }^{2}$ However, this method of rice establishment requires immense labour and water. ${ }^{3}$ Out of the total amount of water $(\sim 150 \mathrm{~cm}), 20-25 \mathrm{~cm}$ is used only for puddling (intensive cultivation in wet conditions). Puddling breaks soil aggregates, and soil becomes hard after drying, leading to the development of cracks and thereafter the water requirement increases manifold because of deep percolation through cracks. Puddling also results in poor soil physical conditions for establishing and raising succeeding crops. ${ }^{4}$ In the backdrop of the declining water resources and reduced availability of the labour, the conventionally flooded rice system is losing its sustainability and economic viability. Declined water table, increasing costs of diesel and electricity and climatic changes have further aggravated the problem. Due to these reasons there is a need to shift from the conventionally flooded transplantation to direct seeding. Directseeded rice (DSR) is the oldest method of rice establishment and prior to the late $1950 \mathrm{~s}$, direct seeding was the major method used in developing countries. ${ }^{5}$ At present, $23 \%$ of rice is direct-seeded globally. ${ }^{6}$ DSR is being cultivated successfully in many parts of the world like China, Australia, Malaysia, United States, and Sri Lanka etc. ${ }^{2}$ Transplanted irrigated rice in Southeast Asia, particularly in the Philippines, Malaysia, and Thailand has been largely replaced by DSR. ${ }^{5}$ DSR is being practiced on terraced and sloppy lands of Bangladesh, along the coast and Western Himalayan region of India. In India, direct seeding of rice is largely a low-productivity system more common in rainfed areas. Direct seeding offers such advantages as faster and easier planting, reduced labour and drudgery, earlier crop maturity by 7-10 days, more efficient water use and higher tolerance of water deficit, fewer methane emission (Dry-seededDSR $<$ Wet-seeded-DSR $<$ Transplanted Rice), and often higher profit in areas with an assured water supply. ${ }^{7}$ Direct seeding also eliminates the use of seedlings and related operations such as seeding, nursery preparation and care of seedlings, pulling, bundling, transporting, and transplanting. ${ }^{8}$ Direct seeding is a good alternative of transplanting and yield potential of DSR is equivalent to the transplanted rice under good water management and weed control conditions. ${ }^{9}$ Direct seeding of rice is accomplished by either of the methods as water seeding, wet seeding and dry seeding. ${ }^{2}$ A DSR crop grown without standing water, intended to use less irrigation water than conventional flooded rice, is referred as aerobic rice. Dry-seeding of rice with subsequent aerobic soil conditions eliminates the need of puddling and maintains submerged soil conditions, thus reducing the overall water demand and providing opportunities for water and labour savings. ${ }^{10}$ However, weeds are a serious problem because dry tillage practices and aerobic soil conditions are conducive for germination and growth of weeds, which can cause grain yield losses from 50 to $90 \%{ }^{11}$ The productivity of the DSR is often reported to be lower, mainly due to problems associated with weed management. In order to save water and labour and promote conservation agriculture, with no/reduced tillage, it is absolutely essential to replace puddled transplanting with direct seeding.

Weed scientists can improve the use of organic soil amendments and crop diversification for weed management by improving knowledge of four relevant ecological mechanisms. ${ }^{12}$ Multispecies crop rotations, intercrops and cover crops may reduce opportunities for weed growth and regeneration through resource competition and niche disruption. Secondly, weed species appear to be more 
susceptible to phytotoxic effects of crop residues and other organic soil amendments than crop species, possibly because of differences in seed mass. Thirdly, delayed patterns of $\mathrm{N}$ availability by organic amendments may favour large-seeded crops over small-seeded weeds. In recent years information concerning weed management with tillage (especially zero and reduced tillage) and cultivation machinery has become more prominent. However, ex situ residue incorporation practically in farmer's field is difficult because of bulky in nature and requires more labour for application during rainy season. In situ residue incorporation poses sowing problems of crops and precisions in placement of seeds at right spacing. However, the results of residue incorporation are very encouraging since it helps in build up of organic carbon $^{13}$ and weed suppression ability in soil. Relying on ecological weed management may be a good option to manage weeds in rice based cropping system in view of changing climate and dwindling resource base for farming.

\section{Losses caused by weed flora in direct seeded rice}

Weed is a serious threat to rice and annual worldwide rice yield loss by weed is $15-21 \% .{ }^{14}$ It is estimated that DSR yield is reduced by $60 \%$ and even $100 \%$ due to huge weed infestation. ${ }^{6}$ Ramzan ${ }^{15}$ reported yield reduction up to 48,53 and $74 \%$ in transplanted, direct-seeded in

Table I Major weeds in rice fields in Asia ${ }^{1 / 4}$ flooded conditions and direct-seeded in dry soils respectively. Weed flora in DSR consists of various kinds of grasses, broad leaf weeds and sedges ${ }^{16}$ (Table 1). Community composition of these weeds varies according to crop establishment methods, cultural methods, crop rotation, water and soil management, location, weed control measures, climatic conditions, and inherent weed flora in the area. Echinochloa colona and E. crus-galli are the most serious weeds affecting DSR. The density of these weeds in DSR depends upon moisture condition in the field. E. colona requires saturated soil, so it is more abundant in DSR. In DSR, weeds compete for nutrients, light, space and moisture throughout the growing season. The crop is likely to experience yield reduction, unless weeds are kept free during a part of its growing period. ${ }^{17}$ Under direct seeding of rice, weeds are the biggest biological constraint in all but dry direct seeded rice because they emerge simultaneously with rice seedlings because of the absence of flooding in the early stages. In dry-seeded rice, aerobic soil conditions and drytillage practices, besides alternate wetting and drying conditions, are conducive for germination and growth of highly competitive weeds, which cause grain yield losses of $50-91 \% .^{18}$ They closely resemble rice seedlings and thus it is difficult to differentiate such weeds and remove them in the early growth stages. The weed species Paspalum distichum and E. colona may become dominant in rice grown under zero-tillage. $^{7}$

\begin{tabular}{|c|c|c|c|c|c|}
\hline Grassy weeds & Life cycle & Sedge & Life cycle & Broad leaf weeds & Life cycle \\
\hline Digitaria setigera & Annual & Cyperus iria & Annual & Commelina benghalensis & $\begin{array}{l}\text { Annual or } \\
\text { Perennial }\end{array}$ \\
\hline Digitaria sanguinalis & Annual & Cyperus difformis & Annual & Caesulia axillaris & Annual \\
\hline Digitaria ciliaris & Annual & Cyperus rotundus & Perennial & Eclipta prostrata & Annual \\
\hline Echinochloa colonum & $\begin{array}{l}\text { Annual or } \\
\text { Perennial }\end{array}$ & Fimbristylis miliacea & $\begin{array}{l}\text { Annual or } \\
\text { Perennial }\end{array}$ & Ipomoea aquatica & Perennial \\
\hline Echinochloa & Annual & & & Ludwigia octovalvis & \\
\hline \multicolumn{6}{|l|}{ crus-galli } \\
\hline Eleusine indica & Annual or Perennial & & & Ludwigia adscendens & \\
\hline Ischaemum rugosum & Annual & & & Monochoria vaginalis & \\
\hline Leptochloa chinensis & Perennial & & & Sphenoclea zeylanica & \\
\hline Oryza sativa (weedy rice) & Annual & & & & \\
\hline Paspalum distichum & Perennial & & & & \\
\hline
\end{tabular}

There is a relationship between the timing of weed emergence and the pressure exerted to the crop through competition and resultant losses in crop yield. Yield losses are usually higher when weeds emerge earlier or at the same time as the crop. ${ }^{19}$ Yield continued to decline as the duration of weed competition increased. Yield losses due to weed-crop competition were most pronounced during the period from 30 to 50 days after sowing (DAS). Weed competition beyond 20 DAS resulted in drastic reduction in the number of panicles $\mathrm{m}^{-2}$ and grains panicle $\mathrm{e}^{-1}$ that accounted for lower rice yield. ${ }^{20}$ In field trials of direct-seeded irrigated rice, $95 \%$ of weed-free rice yield was obtained when weeds were controlled up to 32 DAS in wet season and 83 DAS in dry season. ${ }^{21}$ Therefore, an effective and economical weed control strategy needs to be implemented to meet the rising demand of staple food for increasing population in the world.

\section{Preventive measures for weed management}

a) Sowing of clean seed is one of the most important weed management techniques in any crops.

b) Preventing weeds from entering an area may be easier than trying to control them once they have established.

c) Irrigation water is one of the major means of spread of weed seeds and vegetative propagules. Flowing water moves millions of weed seeds from one place to another. So, it is important to keep irrigation channels free of weed infestation to reduce weed spread.

d) In case of heavy weed infestation, it is advisable to rotate the DSR crop with transplanted rice or other methods of rice planting. A 
continuous DSR crop may result in a shift to emergence of new weeds like Digitaria sanguinalis and Leptochloa chinensis. ${ }^{22}$

Other preventive measures like stale seedbed technique, summer tillage, precession land leveling, crop rotation, sowing methods should also be adopted by farmers.

Stale seedbed technique: Stale or false seedbed technique is preventive method of weed management. In stale seedbed technique, after pre-sowing irrigation, fields are left as such and weeds are allowed to germinate and thereafter are killed through cultivation or with the use of non-selective herbicide (e.g., glyphosate) application. This technique reduces both the size of the seed bank and the emergent weed infestation. It has been observed that this technique can reduce weed population by $53 \%$, especially for controlling weeds such as $C$. rotundus. ${ }^{23}$ It can also be implemented by submergence of rice field after 7 and 14 days of weed emergence. Singh et al., ${ }^{24}$ reported 53\% lower weed density in dry- DSR after stale seedbed than without this practice. The initial seedbed preparation is then followed by destruction of the emerging weed seedlings with minimal soil disturbance. ${ }^{25}$ A reduction of $59 \%$ in the density and by $78 \%$ in the fresh weight of E. colona was recorded after using stale bed technique in the Philippines. ${ }^{26}$ Roder et al., ${ }^{27}$ reported that application of glyphosate before planting rice can reduce labour input for weeding by $30-60 \%$. Paraquat application in stale seedbed was more effective than mechanical weeding in dry seeded rice. ${ }^{28}$

\section{Summer tillage}

a) Tillage prior to crop establishment serves mainly to prepare a weed free seedbed. It eliminates established and emerged weeds prior to crop seeding and also moves weed seeds near the soil surface vertically, resulting in weed seed burial. A clean fallow period is the best strategy to reduce seed bank.

b) Shallow tillage coincident with weed emergence periodicity will stimulate germination of weeds, and subsequent tillage kills these seedlings.

c) Cultivation of rice fields before seeding, especially during the summer months, helps in reducing perennial weeds such as $C$. rotundus and Cynodon dactylon. ${ }^{29}$

Precision land leveling: Precision land leveling, obtained with laserdirected equipment, has made an important contribution to weedy rice management in European rice production. ${ }^{30}$ Level or regularly sloping fields enable appropriate water management, which limits weed growth and guarantees uniform emergence of weeds, which in turn makes herbicides more effective.

Crop rotation: The choice and sequencing of crops affects long-term weed population dynamics, and consequently weed management. In traditional farming, rotations comprised of crops with different life cycles were a key component of weed management. Different planting and harvest dates among these crops provide more opportunities for farmers to prevent either plant establishment or seed production by weeds. Rotating rice with a dicotyledonous crop enables the use of graminicides, especially for weedy rice control. Farmers in Central Vietnam rotate rice with mungbean in the dry season. Watanabe et al., ${ }^{31}$ concluded that this was effective for weedy rice management since volunteer rice seedlings failed to survive in mungbean because of insufficient soil moisture. After 4 months, the average per cent viable seed of weedy rice was only $27 \%$ in moist soil conditions, while in submerged soils it reached $57 \%{ }^{32}$ Rotating soybean after rice minimizes the E. crus-galli problem in Thailand. ${ }^{33}$

\section{Sowing methods}

Conventional tillage: Crop establishment methodology is very important factor affecting weed occurrence in DSR. A good stand establishment during the month of June is very difficult because of high temperature which results in seedling mortality. Conventional tillage provides opportunities to mix seed bank and bring more seeds on the soil surface.

Zero tillage: Recently, there have been many reports about the adaptation of DSR using a seed drill. The time taken for drilling rice seeds in an unpuddled field using a manually-operated planter is less than that required for seedling transplanting. Thus, this practice has potential to replace transplanting without any reduction in yield. Zerotillage results in higher yields because of timely sowing, better crop stand, and increased input-use efficiency. ${ }^{34}$ Direct drilling under zerotillage is advantageous as far as weed control is concerned, but severe yield penalties were also noted by many workers. ${ }^{35} \mathrm{~A}$ large proportion of the weed seed bank remains on or close to the soil surface after crop planting in zero-tillage systems, which may promote greater emergence of weed species that require light to germinate. A study showed that seedling emergence of several weeds, including awnless barnyard grass (Echinochloa colona (L.) Link) and southern crabgrass (Digitaria ciliaris (Retz.) Koel) was greater in rice sown under zerotill conditions than after dry tillage. ${ }^{36}$ This was possibly due to the small seed size of these species preventing emergence from the deep burial that occurs with conventional tillage system, and also that these species require light for germination. If a large weed seed bank accumulates on the soil surface after continuous zero-till, the option of deep tillage to bury weed seeds below the maximum depth of emergence could be used as a tool to suppress weed growth. Such a "rotation" to deep tillage would only be effective if it does not bring to the surface large quantities of seeds buried in the previous deep tillage event. To be able to predict this, it is necessary to understand the longevity of the seeds in the soil seed bank.

The practice of zero-till allows the retention of previous crop residues in the field and it is well known that mulches are a good tool for weed management. Mulches normally exclude light penetration and serve as a physical barrier to weed seedling emergence. However, efforts are underway to further improve this technique for better weed control and higher productivity. In zero-tillage the seed bank buried in soil is not allowed to come to the surface soil or new seeds are not ploughed in to the seed bank, but removed by germination at stale seedbed technique. Zero-tillage saves water and wear and tear on tractors, promotes residue management, and helps to reduce air pollution. The advantages of zero-tillage are more in areas where wheat is traditionally sown late in the eastern Indo-Gangetic Plains. Farmers who have adopted zero-tillage and practiced it for 4 years find no deleterious effects. ${ }^{37}$ Following complete protocol of zero till DSR is difficult under Indian farming situation due to small land holdings and other demand of food items which they grow, mainly for family requirement and disturb the land by tillage and other intercultural operations in subsequent seasons.

\section{Cultural methods}

It is interesting to note that before the introduction of chemical weed control, mechanical weeding was supplemented by seedbed 
preparation, crop rotation, land leveling, seed selection, and water management for weed management. ${ }^{38}$ Due to labour shortages herbicides are widely used in DSR that enables timely weed control. But with the evolution of herbicide resistance, scarcity of new herbicide molecules, weed population shifts and increased costs farmers may limit the use of herbicide in future. This has increased interest in the use of cultural approaches, based on understanding of weed biology, in integrated weed management programs. Weed management should be based on following ecological principles which provide sustainable and economical weed control (Table 2).

Table 2 Non chemical methods of managing weeds and ecological principle

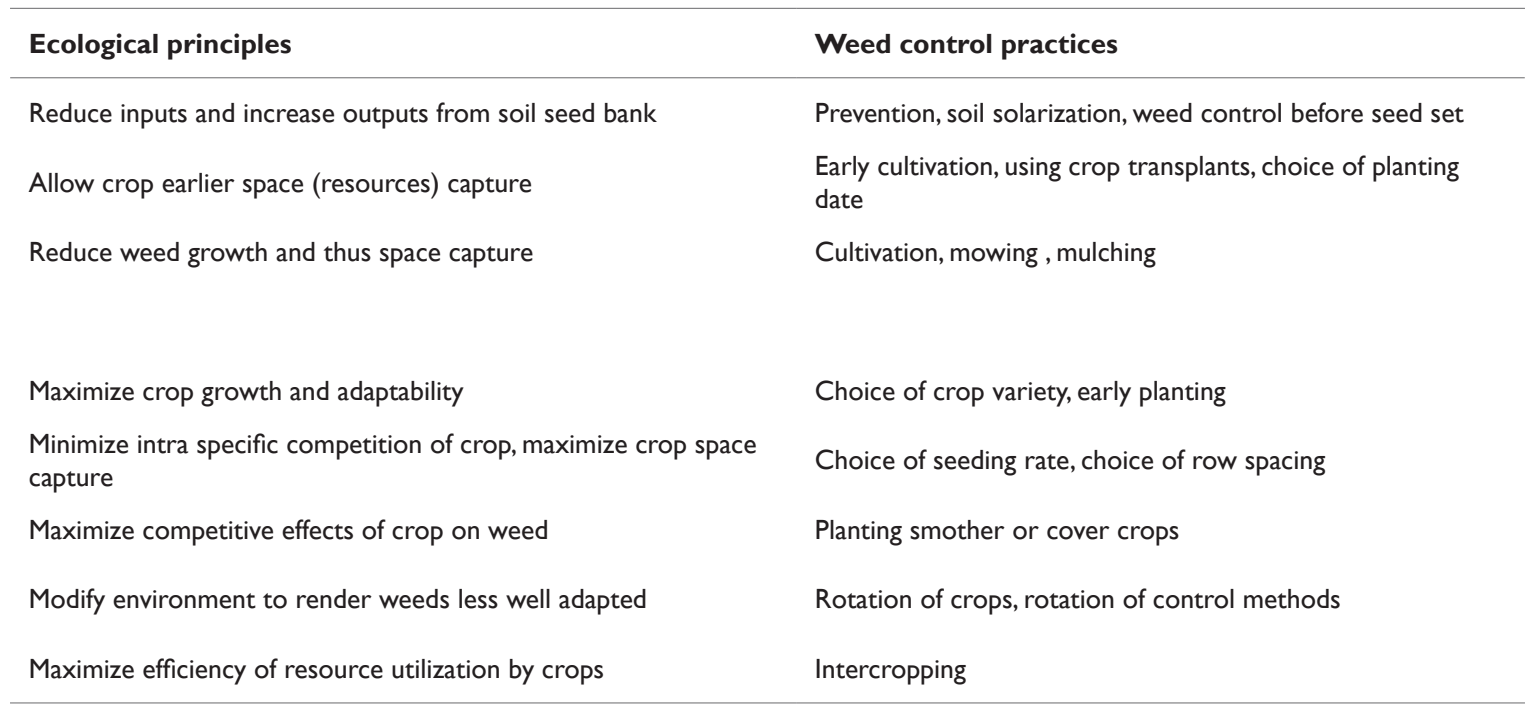

Source: Radosevich et al., ${ }^{115}$

\section{Competitive hybrid and inbred cultivars}

Introduction of short and medium duration hybrids can enhance production in both rainfed as well as irrigated DSR. Hybrid cultivars have better phenotypic plasticity and responds very well under good agronomic practices. Many hybrid cultivars have been introduced by agricultural institutes, SAUs, and research centers and private seed industries for various agroclimatic regions of India. The competitive ability of rice is often associated with traits related to light interception and is correlated with height, leaf area index, specific leaf area, droopy leaves and early tiller production. ${ }^{6}$ Morphological traits that contribute to early ground cover and height are most important traits for competitiveness. Namuco et al., ${ }^{39}$ suggested that easily measurable traits, such as leaf area and dry matter of rice seedlings at an early stage, are correlated with weed competitiveness and therefore, could be used as an indirect tool for screening of rice varieties for competitiveness against weeds. A quick growing and early canopy cover enables a cultivar to compete better against weeds. Research evidences have shown that traditional tall cultivars like Nerica rice exert effective smothering effect on weeds. ${ }^{11}$ Further, it has been observed that early maturing rice cultivars and rice hybrids also have a smothering effect on weeds due to improved vigour and having the tendency of early canopy cover. ${ }^{22}$ Sanint et al., ${ }^{40}$ reported that enhancing crop competitiveness against weeds could reduce weed control costs by $30 \%$. Little is known about the relative importance of shoot and root competition of hybrids and inbred in field conditions in DSR and this may be the subject of future research. Most importantly, there is a need to develop rice varieties suitable for DSR as currently, varieties bred for transplanted rice are being used in DSR. The use of more competitive cultivars has been proposed as a tool to improve weed control in waterseeded rice ${ }^{41}$ Genetic variations in rice varieties exist with respect to competitive ability against weeds. The African rice Oryza glaberrima is a source of a number of these traits that confer competitive ability with weeds, and to produce rice plant types. Javanica type $O$. sativa, $O$. glaberrima, and wild rice have been suggested as possible sources of allelopathic effects, which could be transferred into commercial rice cultivars. ${ }^{42}$ Earlier findings revealed that allelopathic cultivars of rice can control both monocot and dicot weeds under field conditions with some selectivity observed amongst such weeds, suggesting that certain compounds with selective action might be implicated in rice allelopathy ${ }^{43}$ Rice cultivars were reported to supress $H$. limosa and partially suppress Echinocloa crus-galli in many parts of the world. ${ }^{44}$ However, practical utility of allelopathy in weed control needs to be harnessed. Rice cultivar with strong weed competitiveness is deemed to be a low-cost safe tool for weed management. ${ }^{45}$ Competitive rice cultivar effectively suppressed the infestation of Echinochloa spp. and helped reduce herbicide dependency. ${ }^{41}$ Recent researches in rice show that it is possible to increase competitive ability without affecting yielding ability. ${ }^{46}$ Enhanced crop production, independent of weed growth, can be obtained in three different ways:

a. Growing plants that will yield well in spite of weed infestations (weed tolerant crops or cultivars).

b. Growing plants that suppress the surrounding flora (weedsuppressing crops or cultivars). ${ }^{47}$

c. Both strategies used at the same time. Increased crop competitive ability against weed will impair their regenerative capacity, thus decreasing weed abundance in the field over time.

Many of the inbred varieties and hybrids bred for puddled transplanted rice have also been found suitable for DSR. Different rice cultivar are suitable for eastern Uttar Pradesh viz, Arize 6129, Arize 6444, BPT-5204, NDR- 359, Arize 6444 Gold, MTU-7029, Arize Dhani, Arize Prima, Swarna-Sub1, PHB-71. ${ }^{48}$ According to Joshi et al., ${ }^{49}$ the rice cultivar MTU 7209 is suitable for Eastern Uttar 
Pradesh while the cultivar PRH 10 for Haryana, Punjab and Western Uttar Pradesh under direct seeded rice. Early maturing rice cultivars and rice hybrids also have a smothering effect on weeds due to their improved vigour and early crop canopy cover. ${ }^{50} \mathrm{~A}$ field investigation on response of rice varieties to different establishment methods under system of aerobic rice production was carried out by Lenka \& Gulati ${ }^{51}$ at Orissa University of Agriculture and Technology, Bhubaneswar during wet season of 2012. Among the varieties, aerobic rice Pyari, proved superior with higher yield of grain and straw yields, and net return as compared to other two varieties.

\section{Herbicide resistant varieties}

In resource conservation techniques like reduced or zero-tillage, non-selective herbicides like glyphosate, glufosinate and parquet are used to control various weed floras present in the field. Use of herbicide resistant rice varieties will enable farmers to adopt reduced or zero-tillage, and may potentially reduce the intensity of herbicide application while controlling nearly the entire spectrum of weed species. ${ }^{52}$ Three major herbicide resistant (HR) systems currently commercialized are based on resistance to amino acid biosyntheses inhibiting herbicides viz. imidazolinone (IMI), glyphosate and glufosinate and in rice, all three HR systems are being developed. Malik et al., ${ }^{53}$ have suggested that herbicide resistant rice (HR-rice) would dramatically overcome weed problems in direct seeded zero-till rice and reduce the need to puddle soils and keep them continuously submerged. Various risks are associated with use of genetically modified (GM) crops as there may occur gene flow via pollen and seed, resulting in contamination of nearby non-GM crops with the transgene. It may lead to establishment of HR volunteer weeds in the field crop field and nearby non-cropland, and unintended and unanticipated effects on closely related species. ${ }^{54}$ In India, HR-rice is yet to be commercialized. Benefits of herbicide resistant rice varieties must be weighed against risks before the adoption of HR-rice in India. Herbicide resistance rice is Clearfield@, Libertylink@ and Roundup ready@.

\section{Allelopathic rice varieties}

Allelochemicals are produced by different part of rice plant which acts as a tool for weed management. Rice can produce and secrete different allelochemicals into its neighboring environment with various biological effects. Rice variety and origin may regulate allelopathic behavior, for example, japonica rice is more allelopathic than indica and japonica-indica hybrids..$^{55}$ Crude extracts of allelopathic rice cultivars inhibit superoxide dismutase and catalase activities and control barnyard grass seedling ${ }^{56}$ Following rice varieties having allelopathic properties against barnyard grass are IR1108-16-1, UPR82-1-7, Bala, IET1444, IET11754, RAU 4004-127, IR53453-107-2-2.

\section{Seed rate}

Reducing seed rate especially hybrid cultivar will be key input in enhancing profitability of farmer's. Precision seeding machine will be required to apply seeds at proper crop geometry. The use of higher seed rates may increase input cost and weaken seedling vigor, reduce tillering and increase the proportion of infertile tillers, cause $\mathrm{N}$ deficiency, and enhance the incidence of diseases and pests. ${ }^{29}$ For direct drilling of rice, $30-60 \mathrm{kgha}^{-1}$ seed rates are enough for a healthy crop. Only $30 \mathrm{kgha}^{-1}$ seed rate could be used if there was minimal weed pressure in the previous crops. Seed rate could be increased up to $60 \mathrm{kgha}^{-1}$ to compensate for the damages by rats and birds, to partially overcome the adverse effects of herbicides, and to compensate for poor stand establishment if rains occurs immediately after sowing. ${ }^{57}$
Low plant density and high gaps encourage the growth of weeds, and in many cultivars, result in less uniform ripening and poor grain quality. On the other hand, very high plant stand should be avoided because it tends to have less productive tillers, increases lodging, prevents the full benefit of nitrogen application, and increases the chances of rat damage.

\section{Row spacing}

The effect of crop geometry on weed incidence is a different issue from seeding rate..$^{50}$ reported that cultural management techniques, such as reduced crop row spacing, can increase the rice ability to compete against weeds for light. Mahajan \& Chauhan ${ }^{22}$ observed that paired row planting pattern $(15-30-15 \mathrm{~cm}$ row spacing) in DSR had a great influence on weeds as compared to normal row planting system $(23 \mathrm{~cm}$ row spacing). Paired row planting greatly facilitates weed suppression by maintaining rice plant's dominant position over weeds through modification in canopy structure. Rice grown in 30 $\mathrm{cm}$ rows had greater weed biomass and less grain yield than in $15 \mathrm{~cm}$ and $10-20-10 \mathrm{~cm}$ rows. The aerobic rice yield was better in $15 \mathrm{~cm}$ rows and $10-20-10 \mathrm{~cm}$ arrangements than in $30 \mathrm{~cm}$ rows. ${ }^{58}$ Seedlings of awnless barnyard grass and barnyard grass (E. crus-galli (L.) Beauv.) emerged during the first month of the crop growing season, had greater biomass and seeds in DSR planted at $30 \mathrm{~cm}$ rows than at $20 \mathrm{~cm}$ rows. ${ }^{59}$ A study carried at IARI, New Delhi by Kumar et al. ${ }^{60}$ revealed that rice hybrid 'PRH 10' and 'PRH 6' having thinner plant density of 25 plants $\mathrm{m}^{-2}$ had 7.6 and $17.5 \%$ higher grain yield over the 33 and 50 plants $\mathrm{m}^{-2}$, respectively. At Jabalpur, Kewat et al., ${ }^{61}$ observed that number of effective tillers hill ${ }^{-1}$ with wider plant spacing $20 \times 20 \mathrm{~cm}^{2}(9.5)$ were higher as compared to closer plant spacing with $20 \times 15 \mathrm{~cm}^{2}(9.0), 20 \times 10 \mathrm{~cm}^{2}(7.7)$ and $15 \times 15 \mathrm{~cm}^{2}(8.7)$ in hybrid rice 'PA 6201. Verma et al., ${ }^{62}$ reported that with wider plant spacing $20 \times 20 \mathrm{~cm}^{2}$ and $20 \times 15 \mathrm{~cm}^{2}$ number of effective tillers $\mathrm{m}^{-2}$ were significantly higher than that of closer plant spacing of $20 \times 10 \mathrm{~cm}^{2}$ as an experiment conducted on rice hybrid 'PA 6201'. Pol et al., ${ }^{63}$ reported on 'Sahyadri' rice hybrid at Dapoli, Maharashtra number of panicles hill-1 ${ }^{-1}(12.25)$ and panicle weight hill $^{-1}(34.13 \mathrm{~g})$ with wider plant spacing $20 \times 20 \mathrm{~cm}^{2}$ was significantly higher as compared to that with $15 \times 10,20 \times 15$ and $20 \times 10 \mathrm{~cm}^{2}$ plant spacing. They also reported higher grain yield with wider plant spacing of $20 \times 20 \mathrm{~cm}^{2}$ significantly higher to the tune of $11.86,7.96$, and $3.40 \%$ over the spacing $15 \times 10$, $20 \times 10$ and $20 \times 15 \mathrm{~cm}^{2}$, respectively. Roy et al. ${ }^{64}$ reported that the yield of direct seeding of rice can be enhanced with square planting $(20 \times 20 \mathrm{~cm})$ of rice. Chauhan \& Johnson ${ }^{58}$ also reported that total weed biomass is affected by rice row spacing and aerobic rice yields better in 15-cm rows and 10-20-10 cm arrangements than in $30 \mathrm{~cm}$ rows. With regards to methods of establishment, Lenka \& Gulati ${ }^{51}$ observed that the yield of grain and straw and net returns were higher under aerobic transplanting with crop geometry of $20 \mathrm{~cm} \times 20 \mathrm{~cm}$ as compared to direct seeding in $20 \mathrm{~cm}$ apart rows, spot seeding at $20 \mathrm{~cm} \times 20 \mathrm{~cm}$ spacing, spot seeding method $(25 \mathrm{~cm} \times 25 \mathrm{~cm})$ and aerobic transplanting $(25 \mathrm{~cm} \times 25 \mathrm{~cm})$. It also recorded higher values of yield attributing characters, leaf area index, nutrient uptake and field water use efficiency. Rice genotype PHB 71 was significantly superior to NDR 359 with respect to yield attributes, grain yield, economics, nutrient uptake and soil health. Similarly wider row spacing of $30 \mathrm{~cm} \times 30 \mathrm{~cm}$ significantly favored higher values of yield attributes, grain yield, economics, nutrient uptake, and soil health due to profuse root growth. ${ }^{65}$ More research is required in hybrids row to row as well as plant to plant distance because hybrid cultivar has more phenotypic plasticity (High tillering ability, more LAI). 


\section{Crop residue/straw mulching}

Crop residues on the soil surface, as mulch, can influence germination and emergence of many weeds by altering the physical and chemical environments surrounding the seeds. The environmental factors include lower soil temperatures, shading, physical obstruction provided by mulch itself, allelopathy and toxic microbial products. The impact of crop residues on weed emergence, however, depends on the quantity and allelopathic potential of the residue and the weed species. The spreading of mulch on the soil surface reduces evaporation, saves water, protects from wind and water erosion, and suppresses weed growth ${ }^{66}$ Mulching + dryland weeder at 20 DAS proved more effective in dry-seeded rice grown without herbicide use. ${ }^{67}$ In the Philippines, seedling emergence of several weed species has been reported to be influenced by rice residue ( 0 to 6 tha $\left.^{-1}\right)$ although the extent of the response varied between weed species. In India, a mulch of previous wheat crop residue at 4 tha $^{-1}$ reduced annual and broadleaved weed densities in dry-seeded rice compared with no mulch. ${ }^{66}$ Addition of crop residues can reduce seedling emergence of several weed species, but the quantities required to cause a substantial reduction in weed densities may be greater than those normally found in fields after harvest. Seed-drills, such as the Turbo Happy seeder and rotary-disc, are capable of seeding into loose residue of up to 6 tha $^{-1}$. It will be important, however, to balance the quantity of residue required to suppress weeds with quantities that will not hinder rice emergence in direct-seeded systems. Devasinghe et al., ${ }^{68}$ observed that the application of rice straw mulch at the rate of $4 \mathrm{t} / \mathrm{ha}$ was effective in weed management under direct wet seeded rice method. Rice straw can stay long in the field due to higher lignin and silica contents as well as low protein and digestibility. ${ }^{69}$ The nutrients contents of the rice straw will be recycled and used as organic fertilizer ${ }^{70}$ as well as feeds for feeding the soil microbes ${ }^{71}$ in the SRI fields, which increase the fertility of the soil especially potassium and nitrogen. ${ }^{72}$ The new approaches of using rice straw for controlling weeds in different crops, indicated that rice straw can be used for mulching, which benefits in preventing weed growth as well as supplies organic matter for $\mathrm{N}$-fixation by heterotrophic $\mathrm{N}$-fixing microorganisms. ${ }^{73}$ Thus, use of rice straw as fertilizer as well as suppressing the weed growth due to its allelopathic potential can be a good approach to reduce the herbicide load. Singh $\& \mathrm{Guru}^{74}$ observed that weed population and weed dry matter was lower at all the doses $\left(100 \mathrm{~g} / \mathrm{m}^{2}, 200 \mathrm{~g} / \mathrm{m}^{2}\right)$ of rice straw incorporated with the lowest in $500 \mathrm{~g} / \mathrm{m}^{2}$ rice straw treatment. Grain yield was also higher at all the doses of rice straw incorporation while it was lowest $(2658 \mathrm{~kg} / \mathrm{ha})$ in the weedy treatment. Highest grain yield $(3,925 \mathrm{~kg} /$ ha) was obtained, irrespective of cultivars, in the treatment with the highest rice straw incorporation $\left(500 \mathrm{~g} / \mathrm{m}^{2}\right)$. A total of 17 compounds were recorded in the straw. Among these, four compounds could be identified after comparing with phenolic standards. These were gallic acid, p hydroxy benzoic acid, ferulic acid and vanillic acid. Crop residue may be a good option for weed control as well improvement of soil health, however, availability and application of crop residue manually will be a major constraint in large area.

\section{Cover crops and live mulching}

Living mulches are plants grown with a cash crop and planted either before or with a main crop and maintained as a living ground cover throughout the growing season. They are usually not grown for harvest or direct profit but, instead, to provide ecological benefits including protecting soils from erosion, improving soil fertility, providing traffic lanes, suppressing weeds and reducing pest populations. ${ }^{75}$ These secondary intercropped species are often referred to as smother crops. ${ }^{76}$ Smother crops should be species that establish more rapidly than weeds and whose peak period of growth coincides with that of early weed emergence but does not coincide with that of crop. Ideally the smother crop should suppress weed establishment during the critical period for weed establishment, i.e. the period when emerging weeds will cause a loss in crop yield. ${ }^{77}$ Interference with weeds may also result from inclusion of allelopathic plants, that are believed to release chemical compounds (either directly or through microbial decomposition of plant residues) that inhibit the growth and development of weeds. Experiments have demonstrated that cover crop residues left on the soil surface may have significant suppressive effects on weeds that cannot be attributed to either the physical presence of mulch, e.g., shading and cooling of the soil. Intercropping can reduce both weed density and biomass to a great extent due to decreased light transmission through the canopy. ${ }^{78}$ Moreover, incorporation of cover crop into the soil may add allele- chemicals to the soil to prevent germination and establishment of weeds.$^{79}$ Weed control in living mulch is in fact vegetation management. The living mulch needs to be suppressed, normally with herbicides that also will control weeds present in the living mulch and, if persistent, those emerging later. Sesbania is a legume used as a green manure in rice cultivation either as pre-rice or inter or mixed crop with rice. It is sown at $25 \mathrm{~kg} / \mathrm{ha}$ together with rice. After 25-30 days of growth, when Sesbania is about $30-40 \mathrm{~cm}$ tall, it is killed with $2,4-\mathrm{D}$ ester at 0.50 $\mathrm{kg} / \mathrm{ha}$. This co-culture technology can reduce the weed population by nearly half without any adverse effect on rice yield. ${ }^{80}$ Singh et al., ${ }^{66}$ reported that Sesbania co culture reduced broadleaf and grass weed density by $76-83 \%$ and $20-33 \%$ respectively, and total weed biomass by $37-80 \%$ compared with a sole rice crop. Intercropping dhaincha exclusively for in situ green manuring recorded a higher grain yield of rice (with green manure) than sole rice.$^{81}$ Intercropping green manure crops in dry-seeded rice and its subsequent incorporation is very effective in supplying the required quantity of organic manures to rice with additional benefit of weed suppression. ${ }^{82}$ Beneficial effects of concurrent growing of dhaincha in reducing the weed population and weed biomass were reported by Sankar et al..$^{83}$

\section{Brown manuring}

Many scientists had reported efficacy of brown manuring, however our experiences at Research farm had shown poor growth of Sesbania aculeate when co-cultured with DSR. Sesbania aculeate had performed better as cover crops prior to sowing of DSR, in the month of July the temperature $\left(33.8^{\circ} \mathrm{C}\right)$ is relatively less as compared to June $\left(39.5^{\circ} \mathrm{C}\right)$ in eastern U.P., which does not follow luxuriant growth of Sesbania aculeate. Because of poor growth, the live mulch does not smother weed growth and also the biomass addition to soil is lesser, resulting in poor nutrition to plant. Traditionally, farmers grow green manure crops before rice culture and incorporate them by puddling before transplanting rice seedlings. This means an additional need for irrigation water for the Sesbania crop and fuel costs for incorporating it. Since there is little water in the reservoirs during the peak summers, farmers have not been able to take full advantage of green manuring in rice. In the "brown manuring" practice, rice and Sesbania crops are planted together and allowed to grow for 25-30 days before knocking down the Sesbania crop with 2,4-D ester $(0.40-0.50 \mathrm{~kg} / \mathrm{ha})$. In areas where soil crusting is a problem, germinating Sesbania helps break it and facilitates the emergence of rice seedlings. The brown leaves of sesbania after the herbicide application would serve the purpose of mulch and hence smother the weed flora in rice. This technology reduces weed population by nearly half without any adverse effect on rice yield. ${ }^{23}$ Sesbania surface mulch decomposes very fast to 
supply $\mathrm{N}$ and other recycled nutrients. However, there are also reports that sesbania suppresses the rice crop too. ${ }^{84}$ In rice/wheat cropping system, sequences involving summer cowpea for fodder or Sesbania for green manuring, resulted in significantly lowest population of grasses and sedges. ${ }^{85}$ The cono-weeder incorporation of dhaincha and azolla resulted in higher weed control during early stages. In upland DSR, an integrated strategy of growing cowpea or dhaincha as an intercrop and pre-emergence application of pendimethalin $(1.0 \mathrm{~kg} / \mathrm{ha})$ followed by a manual weeding at 20 DAS has been found appropriate for reducing weed competition. ${ }^{86}$

\section{Water management}

Flooding after herbicide application or hand weeding can suppress subsequent growth of weeds in direct-seeded systems. The importance of water management in weed control in DSR is well known. ${ }^{6}$ There should be enough moisture in the field during the application of pre-emergence herbicides in DSR. Herbicides which give excellent control when applied into water may perform poorly in the absence of standing water (Kumar et al., 2009). Good water management together with chemical weed control offers an unusual opportunity for conserving moisture and lowering the cost of rice production. ${ }^{80}$ The construction of field bunds, which retains water in the paddy, has the potential to significantly increase rice production in West Africa, while also possibly reducing labour requirements for hand weeding. ${ }^{87}$ The importance of water management in weed control in DSR is well known but water management still has to achieve its full potential in many Asian countries through improved land leveling and irrigation control. ${ }^{88}$ Good land levelling by precision land leveller is an entry point for DSR because it:

\section{Facilitates uniform and good crop establishment}

\section{Permits precise and uniform water control and good drainage}

3. Reduces the amount of irrigation water needed

4. Increases cultivation area because of fewer bunds

5. Improves input use efficiency (water, nutrients, and agrochemicals) 6. Increases crop productivity. ${ }^{89}$

Precise water management, particularly during crop establishment phase (first 7-15 days after sowing), is crucial in dry drill-seeded rice. ${ }^{90}$ From sowing to emergence, the soil should be kept moist but not saturated to avoid seed rotting. After sowing in dry soil, applying a flush irrigation to wet the soil if it is unlikely to rain followed by saturating the field at the three-leaf stage is essential. ${ }^{91}$ This practice will not only ensure good rooting and seedling establishment but also enhance the germination of weed seeds. Therefore, early weed control with an effective pre-emergence herbicide is very important to check weed emergence and growth.

\section{Nutrient management}

Both crop and weed species respond to increases in soil fertility. Initial dose of nitrogen application may be delayed to reduce weed growth and nitrogen application should be done after effective weed control and under appropriate soil moisture condition. Organic sources such as crop residues, composts and manures will be a better option because they release nitrogen slowly which may starve weeds initially. Fertilizer application can shift the balance of competitive relationships between crops and weeds. Studies conducted with synthetic $\mathrm{N}$ fertilizers indicate that they can increase both the rate and the total amount of weed germination and may promote weed growth more than crop growth. ${ }^{92}$ Judicious use of fertilizers during early growth stage in combination with other weed management practices may help DSR to compete with weeds. It is important to develop fertilization strategies for crop production that enhance the competitive ability of the crop, minimize weed competition, and reduce the nonpoint source pollution from nitrogen. ${ }^{93}$ To achieve high rice yields, both nitrogen fertilization and weed management are essential. ${ }^{94}$ The proper management of $\mathrm{N}$ in DSR reduces the weed competition, and hence should be applied as per the requirement of the crop. The application of excess amount of $\mathrm{N}$ fertilizer encourages weed growth and reduces yield. Mahajan \& Timsina ${ }^{95}$ reported that when weeds were controlled, rice crop responded to higher amount of $\mathrm{N}$ application but under weedy and partially-weedy conditions, grain yield reduced drastically with higher amount of $\mathrm{N}$ fertilization. Losses from weeds progressively decreased with higher fertility levels due to the greater competitive ability of rice. ${ }^{6}$ Singh et al. ${ }^{96}$ reported that the split application of nitrogen $1 / 4$ at basal $+1 / 2$ at tillering $+1 / 4$ at panicle initiation increased the yield and reduced the weed density and weed dry weight.

\section{Manual and mechanical methods}

Many farmers do not realize that weed control is a limiting factor in crop production. Traditionally, they depend on manual labour to control weeds. By the time weeds are large enough to be removed by hand, damage has already occurred, and hand weeding alone cannot revert the yield loss. Maximum yields can only be achieved if weeds are controlled early because most damage takes place when crop plants are small. Hand weeding can only be done at a time when labour is available but this may not coincide with the best time for weed control. Improving weed management by alleviating labour constraints has repercussions for all aspects of crop production, the sustainability of cropping systems, and the social conditions of farming families. Hand weeding in DSR is more time consuming and not as thorough as in transplanted rice. The weeders damage the rice plants as they move through the fields, especially during early crop growth. They fail to remove some of the grassy weeds or remove rice plants by mistake because of the difficulty in distinguishing some grassy weeds from rice. Also hand weeding is at least five times more expensive than herbicides for weed control in DSR, especially under labour-scarce or high labour cost environments. ${ }^{6}$ Hand weeding in DSR should only be done when there are typical weeds that cannot be controlled by either pre- or post-emergence herbicide application, or when labours are cheap and are in abundant supply. Mechanical weed control may involve weeding the whole crop, or it may be limited to selective inter-row weeding. Desiccation on the soil surface is a critical factor in preventing weed regeneration, and wet conditions after hoeing can decrease the level of control. Hoeing is particularly effective against mature weeds. ${ }^{97}$ Mechanical weeders had been found to be most suitable under wider row spacing $\left(25 \times 25 \mathrm{~cm}^{2}\right)$ wherein conoweeder/ rotary weeder may suppress weed growth at early stages of crop growth. Mechanical weeding may be integrated with preemergence and early post emergence herbicide application. IWM may take care of weedy rice which has become problem in many South East Asian countries where DSR is replacing transplanting. Wider row spacing will give enough opportunity to mechanical weeders to suppress growth of weedy rice. Mechanical weed control and hoeing may also suppress the weeds and increase grain yield in DSR. ${ }^{6}$ Both hand pulling and mechanical hoeing were better than herbicides in suppression of weed and increasing yield. Maximum increase of 
$30 \%$ in grain yield over control was observed in hand pulling and that of $25 \%$ in mechanical hoeing. Both methods also resulted in improved quality and gave maximum percentage of normal kernels that is 60.47 in mechanical hoeing and 60.03 hand pulling..$^{8}$ Hand weeding is the most useful method for controlling annual and certain perennial weeds that usually do not regenerate from underground parts. ${ }^{99}$ Normally 2-3 manual weeding at appropriate stages have been found to be effective for a desired level of weed control in DSR. The first weeding should be done at 20-25 DAS in dry-seeded rice and at 25-30 DAS in wet-seeded rice, followed by a second weeding at 4550 DAS. Further weeding will depend on the actual field conditions. Under high rainfall situations, three weeding at 15,30, and 60 DAS produced grain yields on at par with a crop kept free from weeds throughout the season. Two weeding done at either 15 or 30 or 15 and 45 DAS provided higher net returns. ${ }^{29}$ Trung et al., ${ }^{100}$ estimated that from 150 to 200 person-days /ha were required to keep rice crops free of major weeds using manual weeding alone. In India, under lowland conditions, it takes about 200-250 hours ha-1 for hand weeding in a DSR field, depending on the weed infestation.

In a row-seeded or transplanted rice field, where weeds can be controlled by the use of mechanical weeders, it takes only about 5060 hours ha ${ }^{-1}$ depending upon weed infestation and soil conditions. When the rice plants are 10-14 days old, a rotary weeder is passed through the field incorporating strips of rice seedlings into the soil so that the rice that is left appears as a row sown crop. Harrowing has been found effective in direct seeded rice, especially when the crop plants are larger than weeds to escape damage. ${ }^{101}$ Singh \& Singh ${ }^{25}$ observed that hand weeding twice (at 15 and 30 DAS) was found to be superior in managing weeds in DSR than all sequentially applied herbicide treatments. Power driven mechanical weeder is required to save human labour and time for DSR to manage weed initially by shallow tillage. This technique will also be helpful in managing weedy rice problem.

\section{Bio-control agents}

Many mycoherbicides have been reported for control of weeds. COLLEGO, a powder formulation of Colletotrichum gloeosporioides (Penz.) Sacc. f. sp. aeschynomene, was registered in 1982 for the control of northern joint vetch (Aeschynomene virginica (L.) B.S.P.) in rice. ${ }^{6}$ A rust fungus Puccinia canaliculata is being developed and commercialized in the United States for the control of yellow nut sedge. ${ }^{102}$ Despite the demonstrated efficacy of some bio-herbicides under laboratory test conditions, adoption has been rare. The usage of ducks ${ }^{103}$ and water birds ${ }^{104}$ was also found effective in managing weeds and hence may be used as a components of weed management in DSR systems. The combination of common carp and grass carp in the irrigated lowland rice-fish farming system provided good suppression of F. miliacea, C. iria, and S. maritimus. ${ }^{105}$ In certain parts of Tamil Nadu, where rice is grown traditionally, farmers are effectively managing the nutsedge (C. rotundus) problem by using pigs. ${ }^{106}$ Trichoderma viride and Gliocladium virens have been found to control Phalaris minor in wheat and Echinochloa spp. in rice under laboratory conditions without any adverse affect on the crop. ${ }^{86}$

\section{Integrated weed management practices}

Considering the diversity of weed problems in different rice cultures, no single method of control, whether cultural, manual, mechanical, or chemical, would be sufficient to provide seasonlong weed control under all situations. ${ }^{107}$ Manual weeding is not only labour intensive but their timely availability is also a problem. Chemical weed control on the other hand may lead to environmental pollution. Herbicides are used to control weeds in DSR, but because of concerns about the evolution of herbicide resistance and a scarcity of new and effective herbicides, there is a need to integrate other weed management strategies with herbicide use. In addition, because of the variability in the growth habit of weeds, any single method of weed control cannot provide effective and season-long control in DSR. Various weed management approaches need to be integrated to achieve effective, sustainable, and long-term weed control in DSR. The resilience of weed populations under intensive herbicide use, buildup of weed species tolerant of the control methods used, and increasing public concern about indiscriminate pesticide use and its effects on the environment and human health have led to widespread appreciation of the integrated weed management concept. ${ }^{108}$ Integrated weed and crop management is not a new concept, in theory, so improved techniques need not be alien to farmers. Weed control, whether done consciously or not by farmers, is often achieved by a combination of crop production practices and specific weed management activities. Herbicides may continue to play key role in weed control of directseeded rice in developed countries and in majority of direct-seeded rice growing developing countries as a component of integrated weed management. The use of a wider spectrum of chemical modes of action may also help delay the development of herbicide resistance. ${ }^{109}$ Following pre and post emergence herbicide may be integrated with other practices to control weeds effectively (Table 3 ). It is essential, however, to evaluate the environmental and health consequences of potential technologies that are based on chemical means of weed control. Effective weed control in DSR was reported by the integration of herbicides with other practices such as crop rotations, crop competitiveness, mulching and hand weeding ${ }^{6}$ (Table 4).

Table 3 Different pre- and post-emergence herbicides used in dry-seeded rice

\begin{tabular}{lll}
\hline Herbicide & Dose (g/ha) & $\begin{array}{l}\text { Application time (days } \\
\text { after sowing) }\end{array}$ \\
$\begin{array}{ll}\text { Pendimethalin } \\
\text { Oxadiargyl }\end{array}$ & 1000 & $\begin{array}{l}\text { 3-Jan } \\
\text { B-Jan }\end{array}$ \\
$\begin{array}{l}\text { Bispyribac-sodium } \\
\text { Pyrazosulfuron }\end{array}$ & 25 & $15-25$ \\
Penoxsulam & 25 & $15-25$ \\
Azimsulfuron & 30 & $15-25$ \\
Fenoxaprop & 60 & $15-25$ \\
(with safener) & & $15-25$ \\
Cyhalofop & 90 & $15-25$ \\
2,4-D ester or amine & 500 & $15-25$ \\
Metsulfuron & 4 & $15-25$ \\
Ethoxysulfuron & 18.75 & $15-25$ \\
Metsulfuron + & 4 & $15-25$ \\
Chlorimuron & & \\
\hline
\end{tabular}

Source: Chouhan \& Yadav ${ }^{116}$ 
Table 4 Following IWM practices should be followed by farmers in dry direct seeded Rice

\begin{tabular}{|c|c|c|c|}
\hline S.No. & $\begin{array}{l}\text { Location } \\
\text { (Indian } \\
\text { condition) }\end{array}$ & IWM practice & References \\
\hline I & $\begin{array}{l}\text { Varanasi, Uttar } \\
\text { Pradesh }\end{array}$ & $\begin{array}{l}\text { Pendimethalin } 1.0 \mathrm{~kg} / \mathrm{ha} \mathrm{fb} \text { azimsulfuron } 17.5 \mathrm{~g} / \mathrm{ha}+\text { bispyribac } 25 \mathrm{~g} / \mathrm{ha} \text { I } 5 \text { DAS fb I HW significantly } \\
\text { reduced weed density and weed biomass and increase rice grain yield. }\end{array}$ & Yadav et al. ${ }^{117}$ \\
\hline 2 & $\begin{array}{l}\text { Terai of } \\
\text { Uttaranchal, }\end{array}$ & $\begin{array}{l}\text { When the stale-seed bed technique was combined with the application of pre-emergence herbicide, } \\
\text { pendimethalin within } 2 \text { DAS. }\end{array}$ & Singh et al. ${ }^{118}$ \\
\hline 3 & $\begin{array}{l}\text { Pantnagar, } \\
\text { Uttarnchal }\end{array}$ & $\begin{array}{l}\text { Pre-emergence application of pendimethalin at } 1.0 \mathrm{~kg} \text { a.i. ha- }{ }^{\prime}+\text { farm wastes as mulch }\left(7.5 \mathrm{t} \mathrm{ha-}-^{-}\right)+ \\
\text {one hand weeding at } 45 \text { DAS of DSR resulted in effective weed control and higher crop yield }\end{array}$ & Singh et al. ${ }^{119}$ \\
\hline 4 & Haryana & $\begin{array}{l}\text { Integrated weed management with Sesbania (intercropped and incorporated at } 4 \text { WAS) + } \\
\text { pendimethalin @ I kg a.i. ha-' may be adopted for suppressing weeds and achieving higher } \\
\text { productivity of direct seeded upland rice. }\end{array}$ & $\begin{array}{l}\text { Sardana et } \\
\text { al. }^{120}\end{array}$ \\
\hline 5 & West Bengal & $\begin{array}{l}\text { Butachlor @ I.25 kg/ha as pre-plant surface application + brown manuring + POE application of } \\
2,4-D @ 0.50 \mathrm{~kg} / \mathrm{ha} \text { at } 40 \text { days after sowing recorded highest grain yield (4.36 and } 4.18 \text { tonnes } / \mathrm{ha}) \text {. }\end{array}$ & $\begin{array}{l}\text { Maity \& } \\
\text { Mukherjee }{ }^{|2|}\end{array}$ \\
\hline 6 & $\begin{array}{l}\text { Palampur, } \\
\text { Himachal }\end{array}$ & $\begin{array}{l}\text { Enhanced dry-seeded rice competitiveness against weeds was observed with } 100 \mathrm{~kg} \text { ha-' seed rate + } \\
\text { oxyfluorfen } 0.25 \mathrm{~kg} \text { a.i. ha-' ( } 3 \text { DAS) + halod }\end{array}$ & $\begin{array}{l}\text { (Angiras } \\
\text { and Sharma, } \\
\text { 1998) }\end{array}$ \\
\hline 7 & $\begin{array}{l}\text { Pantnagar, } \\
\text { Uttarakhand }\end{array}$ & $\begin{array}{l}\text { Herbicide (pendimethalin at } 1.0 \mathrm{~kg} \text { a.i. ha- }{ }^{\prime} \text { ) as pre-emergence supplemented with two hand weedings } \\
\text { were needed to reduce weed growth in zero till dry-seeded rice }\end{array}$ & Singh et al. ${ }^{123}$ \\
\hline 8 & $\begin{array}{l}\text { Jabalpur, Madhya } \\
\text { Pradesh }\end{array}$ & $\begin{array}{l}\text { In irrigated dry-seeded rice, integration of pendimethalin } 1.0 \mathrm{~kg} \text { a.i. ha- }{ }^{\prime} \text { or pretilachlor } 0.75 \mathrm{~kg} \text { a.i. ha- }{ }^{\prime} \\
\text { with I hand-weeding at } 30 \text { DAS or sequential application of pre-emergence herbicides followed by } \\
\text { post-emergence application of } 2,4-\mathrm{D}\left(0.5 \mathrm{~kg} \text { a.i. ha- }{ }^{-}\right) \text {and fenoxaprop }\left(0.07 \mathrm{~kg} \text { a.i. ha- }{ }^{-}\right) \text {, proved quite } \\
\text { effective against weeds }\end{array}$ & $\begin{array}{l}\text { (Mishra \& } \\
\text { Singh, 2008) }\end{array}$ \\
\hline 9 & Cuttak & $\begin{array}{l}\text { It is suggested that an integrated weed management strategy involving summer ploughing, thiobencarb } \\
\text { application and inter-crop cultivation is essential for effective weed control in direct-sown, flood- } \\
\text { prone, lowland rice, in order to ensure higher } \mathrm{N} \text {-use efficiency and crop productivity }\end{array}$ & Sharm ${ }^{124}$ \\
\hline
\end{tabular}

\section{Management of weedy rice}

Regarding land preparation, repeated rot ovation is effective to reduce weedy rice population in rice fields. ${ }^{110}$ The majority of the farmers usually apply only three times tillage. Greater numbers of tillage are able to reduce weedy rice in soil seed bank through enhancing germination and then ploughing down. ${ }^{11}$ Zainal \&Azmi ${ }^{112}$ proposed sequential tillage during land preparation to reduce weedy rice population. Other measures can be used to control weedy rice and these include the use of weed-competitive varieties, transgenic herbicide resistant rice varieties, certified and clean rice seeds, sowing with high seed rates, flooding of rice field at the early stage of growth, crop rotation and use of clean machinery. ${ }^{113}$

\section{Conclusion}

Weeds are location specific and the nature and intensity of weed flora are usually governed by the ecosystems under which it is grown. There is need to give fine tuning to the low cost integrated weed management technology involving stale seed bed technique, suitable aerobic genotypes, cultural, physical, and mechanical and use of low doses of herbicides for different ecosystems in the different regions. More research is needed to develop ecologically sustainable integrated weed management systems for small and marginal farmers. High yielding rice varieties suitable for DSR under different agroclimatic conditions must possess the desirable traits, viz. vigorous growth; weed suppressing ability, germinating ability under moisture stress, tolerant to micronutrient deficiency. ${ }^{125}$ There is need to improve the productivity of DSR which is low due to inadequate nutrient management, inefficient water management and problem associated with weed management. Timely use of hybrids with optimum spacing during mid May to mid- June (or 15-20 days before commencement of monsoon) is deciding factor for the success of the crop. Irrigation water supply must be ensured at the sowing time and also at the same time special concern given on weed management. Organic amendments, cover crops(Sesbania culture i.e. one month before sowing of rice and live mulching (Sesbania coculture) shall be integrated in DSR production technology to break the niches of weeds and sustain the DSR culture. The problem of weedy rice is coming up in direct seeding rice especially in canal irrigated direct seeded areas. Strategic approach in tackling this menace is very much required. There is also need to address broad spectrum herbicide formulation / jumbo formulations to save the cost of herbicide application because most of the Indian farmers are small and marginal. ${ }^{126-141}$

\section{Acknowledgements}

None.

\section{Conflict of interest}

The author declares there is no conflict of interest. 


\section{References}

1. Ehsanullah AN, Jabran K, Habib T. Comparison of different planting methods for optimization of plant population of rice (Oryza sativa L.) in Punjab (Pakistan). Pakistan Journal of Agricultural Sciences. 2007;44:597-599.

2. Farooq M, Kadambot, Siddique HM, et al. Rice direct seeding: Experiences, challenges and opportunities. Soil Tillage Research. 2011;111(2):87-98.

3. Bouman BAM, Humphreys E, Tuong TP, et al. Rice and water. Advances in Agronomy. 2007;97:187-237.

4. Tripathi RP, Gaur MK, Rawat MS. Puddling effect on soil physical properties and rice performance under shallow water table conditions of Tarai. J Indian Soc Soil Sci. 2003;51(2):118-124.

5. Pandey S, Velasco 1. Trends in crop establishment methods in Asia and research issues. In: Toriyama $\mathrm{K}$, editor. Rice is life: perspectives for the $21^{\text {st }}$ century. International Rice Research Institute, Los Baños, Philippines and japan international research center for agricultural sciences: Japan;2005:178-181.

6. Rao AN, Johnson DE, Sivaprasad B, et al. Weed management in directseeded rice. Advances in Agronomy. 2007;93:153-255.

7. Balasubramanian V, Hill JE. Direct seeding of rice in Asia: emerging issues and strategic research needs for the 21st century. In: Pandey et al, editors. Direct seeding: research strategies and opportunities. Proceedings of the International Workshop on Direct Seeding in Asian Rice Systems. Los Baños (Philippines): International Rice Research Institute;2002:15-39.

8. Serrano FB. Twenty-six years of rice research and development. Philippines: National Research Council of the Philippines; 1975: 122 p.

9. Awan IU, Alizai HU, Chaudhry FM. Comparative study of direct seeding and transplanting methods on the grain yield of rice. Sarhad Journal of Agriculture. 1989;5:119-124.

10. Sharma PK, Bhushan L, Ladha JK. Crop water relations in rice-wheat cropping under different tillage systems and water management practices in a marginally sodic, medium-textured soil. In: Bouman, BAM, et al. editors. Water-wise Rice Production. Philippines: Proceedings of the International Workshop on Water-Wise Rice Production;2002:223-235.

11. Prasad R. Aerobic rice systems. Advances in Agronomy. 2011;111:207247.

12. Liebman M, Davis AS. Integration of soil, crop and weed management in low-external-input farming systems. Weed Research. 2000;40(1):27-47.

13. Gangwar KS, Singh KK, Sharma SK et al. Alternative tillage and crop residue management in wheat after rice in sandy loam soils of IndoGangetic plains. Soil and Tillage Research. 2006;88(1-2):242-252.

14. Oerke EC, Dehnf HW, Schonbeck F, et al. Crop Production and Crop Protection Estimated losses in Major Food and Cash Crop. Elseiver; Netherlands; 1994;808.

15. Ramzan M. Evaluation of various planting methods in rice-wheat cropping system. Pakistan: Rice crop Report; 2003:4-5.

16. Mahajan G, Chauhan BS, Johnson DE. Weed management in aerobic rice in north western Indo-Gangetic Plains. Journal of Crop Improvement. 2009;23(4):366-382.

17. Azmi M, Chin DV, Vongsaroj P, et al. Emerging issues in weed management of direct-seeded rice in Malaysia, Vietnam, and Thailand. Advances in Agronomy. 2007;93:196-198.

18. Fujisaka S, Moody K, Ingram K. A descriptive study of farming practices for dry seeded rainfed lowland rice in India, Indonesia and Myanmar. Agriculture Ecosystem \& Environment. 1993;45(1-2):115-128.
19. Aldrich RJ. Predicting crop yield reduction from weeds. Weed Technology. 1987;1(3):199-206.

20. Khaliq A, Matloob A. Weed-crop competition period in three fine rice cultivars under direct-seeded rice culture. Pakistan Journal of Weed Sciences Research. 2011;17(3):229-243.

21. Johnson DE, Wopereis MCS, Mbodj D, et al. Timing of weed management and yield losses due to weeds in irrigated rice in the Sahel. Field Crops Research. 2004;85(1):31-42.

22. Mahajan G, Chauhan BS. Effects of planting pattern and cultivar on weed and crop growth in aerobic rice system. Weed Technology. 2011;25(4):521-525.

23. Gopal Ravi, Jat RK, Malik RK, et al. Direct dry seeded rice production technology and weed management in rice based systems. Technical Bulletin. International Maize and Wheat Improvement Center, New Delhi India. 2010;1-28.

24. Singh S, Chhokar RS, Gopal R, et al. Integrated weed management: A key to success for direct-seeded rice in the Indo-Gangetic Plains. In: JK Ladha, et al. editors. Integrated Crop and Resource Management in the Rice-Wheat System of South Asia, Los Banos, Philippines: International Rice Research Institute;2009:261-278.

25. Singh MK, Singh A. Effect of stale seedbed method and weed management on growth and yield of irrigated direct-seeded rice. Indian Journal of Weed Science. 2012;44(3):176-180.

26. Moody K. Weed control in dry-seeded rice. In: Report of a workshop on cropping system research in Asia. International Rice Research Institute; Philippines; 1982.

27. Roder W, Phenchanh S, Maniphone S. Weed management strategies aimed at reducing labour for upland rice production. In: Roder W, editor. Slash-and-burn rice systems in the hills of northern lao pdr: description, challenges, and opportunities. Philippines: International Rice Research Institute;2001:93-102.

28. Renu S, Thomas CG, Abraham CT. Stale seedbed technique for the management of sacciolepis interrupta in semi-dry rice. Indian Journal of Weed Science. 2000;32(3-4):140-145.

29. Singh S, Ladha JK, Gupta RK, et al. Weed management in aerobic rice systems under varying establishment methods. Crop Protection. 2008;27:660-671.

30. Ferrero A, Vidotto F. Weed management in European rice fields. International Rice Commission Newsletter (FAO). 2007;56:44-51.

31. Watanabe H, Vaughan DA, Tomooka N. Weedy rice complexes: case study from Malaysia, Vietnam and Suriname. Vietnam: Paper presented at the International Symposium on Wild and Weedy Rices in Agroecosystems; 1988.

32. Chin DV, Hach CV, Thanh NC, et al. The weedy rice situation in Vietnam. FAO Global Workshop on Red Rice Control, Rome (Italy): Food and Agriculture Organization of the United Nations;2000:67-74.

33. Vongsaroj P, Price CE. Weed control in rice-soybean rotations. Indonesia. In: Proceeding 11th Asian-Pacific Weed Science Society Conference; 1987.

34. Hobbs PR, Gupta RK. Resource-conserving technologies in the ricewheat system. In: Improving the productivity and sustainability of ricewheat systems: issues and impacts. ASA Special Publication; Madison, Wis. (USA): American Society of Agronomy, Crop Science Society of America, Soil Science Society of America;2003:149-172.

35. Brar LS, Mahajan G, Sardana V. Weed management practices for basmati rice planted by different methods. China. In: Proceeding of Second International Conference on Sustainable Agriculture for Food, Energy and Industry; 2002. 
36. Chauhan BS, Johnson DE. Influence of tillage systems on weed seedling emergence pattern in rainfed rice. Soil and Tillage Research. 2009;106(1):15-21.

37. Malik RK, Yadav A, Singh S. Herbicide resistance management and evaluation of zero-tillage: a success story. Research Bulletin, Haryana Agricultural University; India; 2002.

38. Matsunaka S. Evolution of rice weed control practices and research: world perspective. In: Proceedings of the Conference on Weed control in rice. 31 August-4 September 1981 Jointly sponsored by the International Rice Research Institute and the International Weed Science Society. International Rice Research Institute Los Baños, Laguna, Philippines;1983:5-18.

39. Namuco OS, Cairns JE, Johnson DE. Investigating early vigour in upland rice (Oryza sativa L.). Part I. Seedling growth and grain yield in competition with weeds. Field Crops Research. 2009;113(4):197-206.

40. Sanint LR, Correa-victoria FJ, Izquierdo J. The current situation and issues in rice production in latin america and carribbean. In: Proceedings of International Rice Conference. Rome: FAO; 1998: 35 p.

41. Gibson KD, Hil JE, Foin TC, et al. Water seeded rice cultivars differ in ability to interfere with water grass. Agronomy Journal. 2001;93(2):326332 .

42. Johnson DE. Weed management in small holder rice production in the tropics. National IPM Network, University of Minnesota; 1996;1-8.

43. Olofsdotter MB, Courtois B. Improving crop competetive ability using allelopathy: an example from rice. Plant breed. 2002;121(1):1-9.

44. Gealy D, Ottis B, Talbert R, et al. Evaluation and improvement of allelopathetic rice germplasm at Stuttgart, Arkanas, USA. In Proceedings of Fourth World Congress on allelopathy August 21-26, 2005. 2005;157163.

45. Gibson KD, Fischer AJ. Competitiveness of rice cultivars as a tool for cropbased weed management. In Weed Biology and Management. Inderjit editor. Kulwer Academic Publisher; the Netherlands;2004:517-537.

46. Olofsdotter M, Navarez D, Rebulanan M. Rice allelopathy - where are we and how far can we get? Brighton. BCPC. Brighton Crop Protection Conference. 1999:99-104.

47. Lemerle D, Gill GS, Murphy CE, et al. Genetic improvement and agronomy for enhanced wheat competitiveness with weeds. Australian Journal of Agriculture Research. 2001;52(5):527-548.

48. Yadav S, Malik RK, Humphreys E. Guidelines for dry seeded rice (DSR) in the Eastern Gangetic Plains of India. CSISA and IFAD joint publication. International Rice Research Institute (IRRI) and the International Maize and Wheat Improvement Center (CIMMYT); 2013:32.

49. Joshi E, Kumar D, Lal B, et al. Management of direct seeded rice for enhanced resource-use efficiency. Plant Knowledge Journal. 2013;2(3):119-134.

50. Chauhan BS, Johnson DE. Relative importance of shoot and roo competition in dry- seeded rice growing with jungle rice (Echinochloa colona) and ludwigia (Ludwigia gyssopifolia). Weed Science, 2010a;58(3):295-299.

51. Lenka S, Gulati JML. Response of rice varieties to different establishment methods under system of aerobic rice production. An International Journal on Rice. 2014;51(2):168-171.

52. Duke SO. Weed Management: Implications of herbicide resistant crops. In: Workshop on Ecological effect of Pest Resistance Genes in Management of Ecosystems. USA; 1999.

53. Malik RK, Yadav A, Hobbs PR. Integrated weed management and conservation agriculture in the Indian rice-wheat cropping system. In:
Proceedings of the 57th Annual Meeting of the North eastern Weed Science Society. Baltimore, USA;2003:36-142.

54. Kwon YW, Kim DS, Yim KO. Herbicide-resistant genetically modified crop: assessment and management of gene flow. Weed biology Management. 2001;1(2):96-107.

55. Khanh TD, Elzaawely AA, Chung IM. Role of allelochemicals for weed management in rice. Allelop J. 2007;19(1):85-96.

56. Lin WX, Kim KU, Liang KJ. Hybrid rice with allelopathy. In: Kim KU, editors. Proceedings of the International Workshop in Rice Allelopathy Taegu, Korea: Kyungpook National University; 2000:49-56.

57. Mahajan G, Gill MS, Singh K. Optimizing seed rate for weed suppression and higher yield in aerobic direct seeded rice in North Western IndoGangetic Plains. Journal of New Seeds. 2010;11(3):225-238.

58. Chauhan BS, Johnson DE. Row spacing and weed control timing affect yield of aerobic rice. Field Crops Research. 2011;121(2):226-231.

59. Chauhan BS, Johnson DE. Implications of narrow crop row spacing and delayed Echinochloa colona and Echinochloa crus-galli emergence for weed growth and crop yield loss in aerobic rice. Field Crops Research. 2010b;117(2-3):177-82.

60. Kumar A, Mishra BN, Mishra PK. Effect of age of seedlings and plant density on growth and yield of hybrid rice. Annals of Agricultural Research. 2002;23(3):381-386.

61. Kewat ML, Agrawal SB, Agrawal KK et al. Effect of divergent plant spacing and age of seedlings on yield and economics of hybrid rice Indian Journal of Agronomy. 2002;47(3):367-371.

62. Verma AK, Pandey N, Tripathi S. Effect of transplanting spacing and number of seedlings on productive tillers, spikelet sterility, grain yield and harvest index of hybrid rice. IRRN. 2002;27(1):51.

63. Pol PP, Dixit AJ, Thorat ST. Effect of integrated nutrient management and plant densities on yield attributes and yield of Sahayadri hybrid rice. Journal of Maharashtra Agricultural University. 2005;30(3):357-359.

64. Roy HP, Salam MA, Islam MR, et al. Weed infestation and yield performance of boro rice in direct seeding method as influenced by green growth regulator and herbicides. International Journal of Sustainable crop production. 2009;4(1):83-90.

65. Singh K, Singh SR, Singh JK. Effect of age of seedling and spacing on yield, economics, soil health and digestibility of rice (Oryza sativa) genotypes under system of rice intensification. Indian Journal of Agricultural Sciences. 2013;83(5):479-83.

66. Singh S, Ladha JK, Gupta RK, et al. Evaluation of mulching, intercropping with Sesbania and herbicide use for weed management in dry-seeded rice (Oryza sativa). Crop Protection. 2007;26:518-524.

67. Hussain A, Gogoi AK. Non-chemical weed management in upland direct-seeded rice. Indian Journal of Weed Science. 1996;28:89-90.

68. Devasinghe D, Premarathne K, Sangakkara U. Weed Management by Rice Straw Mulching in Direct Seeded Lowland Rice (Oryza sativa L.).Tropical Agricultural Research.2011;22(3):263-272.

69. Hanafi EM, El Khadrawy H, Ahmed W, et al. Some observations on rice straw with emphasis on updates of its management. World Applied Sciences Journal. 2012;16(3):354-361.

70. Nader G, Robinsons P. Rice producers' Guide to Marketing Rice Straw. UCANR Publications; 2010.

71. Bioflora. Definition of Soil Microbe Groups. US AG Florida, Inc.; 2013.

72. Bird J, Eagle A, Horwath W, et al. Long-term studies find benefits, challenges in alternative rice straw management. California Agriculture. 2002;56(2):69-75. 
73. Mendoza TC Samson R. Strategies to avoid crop residue burning in the Philippines context. In: Proceedings International Conference of "Frostbite and Sunburns"Canadian International Initiatives Toward Mitigating Climatic Change International Program (IP) of the Canadian Environmental Network (CEN) and the Salvadom Center for Appropriate Technology (CESTA); 1999.

74. Singh P, Guru SK. Effect of rice straw incorporation on weed management and crop growth in rice. Indian Journal of Weed Science. 2011;43(3\&4):236-238.

75. Hartwig NL, Ammon HU. Cover crops and living mulches. Weed Science. 2002;50(6):688-699.

76. Liebman M, Staver CP. Crop diversification for weed management. In: Ecological Management of Agricultural Weeds Liebman M, editors. Cambridge University Press; Cambridge; 2001;322-374.

77. Buhler DD, Kohler KA, Foster MS. Corn, soybean and weed responses to spring seeded smother plants. Journal of Sustainable Agriculture. 2001;18(4):63-79.

78. Baumann DT, Kropff MJ, Bastiaans L. Intercropping leeks to suppress weeds. Weed Research. 2000;40:359-374.

79. Buhler DD. Challenges and opportunities for integrated weed management. Weed Science. 2002;50(3):273-280.

80. Singh S, Chhokar RS, Gopal R. Integrated weed management: A key for to success for direct seeded rice in Indo-Gangetic Plains. Phillipines: International Rice Research Institute;2009:261-278.

81. Anbumani S, Chandrasekaran B, Nadanassababady T, et al. Split strategies and intercropping dhaincha for in situ green manuring and seed production in wet-seeded rice. Acta Agronomica Hungarica. 2003;51(2):173-179.

82. Mathew J, Bridgit TK, Mathew G. A low cost green manuring technology for dry sown rainfed low land rice. In: Proceedings of the International Symposium on Rainfed Rice for Sustainable Food Security;1996:23-25.

83. Sankar RN, Chandrasekharan B, Nair AK. Evaluation of seeding methods and in situ incorporation of dhaincha (Sesbania aculeata Poir.) on productivity of wet seeded rice. In: Proceedings of the National Symposium on Resource Management for Ecofriendly Crop Production, Tiwari AN, editors. New Delhi: Indian Society of Agronomy;2003:10.

84. Kumar V, Ladha JK. Direct seeding of rice: Recent developments and future research needs. Advances in Agronomy. 2011;111:297-413.

85. Mishra JS, Singh VP. Integrated weed management in dry-seeded irrigated rice (Oryza sativa). Indian Journal of Agronomy. 2008;53:299305 .

86. ICAR 2007, Vision 2025. NRCWS Perspective plan. Indian Council of Agriculture Research; India.

87. Becker M, Johnson DE. Improved water control and crop management effects on lowland rice productivity in West Africa. Nutrient Cycling in Agroecosystems. 2001;59(2):119-127.

88. Hill JE, Mortimer AM, Namuco OS. Water and weed management in direct-seeded rice: Are we headed in the right direction? In: Peng S, editors. Proceedings of the International Rice Research Conference, Rice research for food security and poverty alleviation. Los Baños, Philippines. Los Baños (Philippines): International Rice Research Institute;2000:491-510.

89. Jat ML, Gathala MK, Ladha JK, et al. Evaluation of precision land leveling and double zero-till systems in the rice-wheat rotation: Water use, productivity, profitability and soil physical properties. Soil and Tillage Research. 2009;105(1):112-121.

90. Kumar V, Ladha JK, Gathala MK. Direct drill-seeded rice: A need of the day. Pittsburgh. In: Annual Meeting of Agronomy Society of America;2009:1-5.
91. Bouman BAM, Lampayan RM, Tuong TP. Water Management in Irrigated Rice: Coping with Water Scarcity. Philippines: International Rice Research Institute; 2007:54.

92. Ditomaso JM. Approaches for improving crop competitiveness through manipulation of fertilization strategies. Weed Science. 1995;43(3):491497.

93. Cathcart RJ, Swanton CJ. Nitrogen management will influence threshold values of green foxtail (Setaria viridis) in corn. Weed Science. 2003;51(6):975-986.

94. Begum M, Juraimi AS, Amartalingum R, et al. Effect of Fimbristylis miliacea competition with MR220 rice in relation to different nitrogen levels and weed density. International Journal of Agriculture and Biology. 2009;11(2):183-187.

95. Mahajan G, Timsina J. Effect of nitrogen rates and weed control methods on weeds abundance and yield of direct-seeded rice. Archives of Agronomy and Soil Science. 2011;57(3):239-250.

96. Singh RK, Singh D. Effect of sowing methods and herbicides in direct drilled rice (Oryza sativa). In: the 20th asian-pacific weed society conference, held at Ho Chi Minh City (Vietnam) 7-11 November, 2005. Vietnam: Agricultural publishing house;2005:323-327.

97. Bohrnsen A. Several years results about mechanical weeding in cereals. Communications of the 4th International Conference I.F.O.A.M. France: Non Chemical Weed Control;1993:95-101.

98. Akbar N, Jabran K, Muhammad AA. Weed management improves yield and quality of direct seeded rice. Australian Journal of Crop Science. 2011;5(6):688-694.

99. Baloch MS, Awan IU, Gul H, et al. Effect of Establishment Methods and Weed Management Practices on Some Growth Attributes of Rice. Rice Science. 2006;13(2):131-140.

100. Trung HM, Tan, NT, Cung HA. Present status and prospect of weed control in rice in Vietnam. Japan: Proceedings of the 15th Asian-Pacific Weed Science Society Conference;1995:601-606.

101. Rasmussen J, Accard J. Weed control in organic farming systems. In Ecology and Integrated Farming Systems. Glen DM, editors. Chichester: Wiley; 1995:49-67.

102. Phatak SC. Development and commercialization of rust (Puccinia canaliculata) for biological control of yellow nutsedge (Cyperus esculentus L.). In: Proceedings of the First International Weed Control Congress. Weed Science Society, Victoria, Inc., Australia; 1992:388-390.

103. Furuno T. The power of duck. Integrated rice and duck farming, $1^{\text {st }}$ ed. Australia: Tagari Publications; 2001:1-17.

104. Kendig A, Williams B, Smith CW. Rice weed control. In: Smith CW, editors. Rice, origin, history, technology and production; Wiley; New Jersey; 2003. 457-472 p.

105. Pane H, Fagi AM. Integrated weed control to minimize herbicide application in lowland rice. Philippines. In: International Rice Research Conference. IRRI, Los Baños; 1992. 23 p.

106. Chinnamuthu CR. Pigs manage the world's worst weed, Cyperus species (purple nutsedge); 2004.

107. Yaduraju NT, Mishra JS. Sedges in rice culture and their management. In: Y Singh, et al. editors. Direct Seeding of Rice and Weed Management in the Irrigated Rice-Wheat Cropping System of the Indo-Gangetic Plains. International Rice Research Institute, Los Banos, Philippines and Directorate of Experiment Station, G.B. Pant University of Agriculture and Technology, Pantnagar; India; 2008:191-203.

108. Fryer JD. Recent research on weed management: new light on old practice. In: WW Fletcher, editor. Commonwealth Agricultural Bureaux. Pages in Recent advances in weed research The Gresham Press, Old Working Survey, England; 1983:180-198. 
109. De Datta SK, Baltazar AM. Weed control technology as a component of rice production systems. In: Auld B, editors. Weed Management in Rice. FAO Plant Production and Protection. 1996;139:25-52.

110. Cao QJ, Li BO, Song JP, et al. Impact of weedy rice populations on the growth and yield of direct-seeded and transplanted rice. Weed Biology and Management. 2007;7(2):97-104.

111. Fogliatto S, Vidotto F, Ferrero A. Germination of weedy rice in response to field conditions during winter. Weed Technology. 2011;25(2):252-261.

112. Zainal AH, Azmi M. A new weed problem in rice: Weedy rice. Rice IPM conference-Integrating Science and Peoples in Rice Pest Management. India; 1996:166-174.

113. Azmi M, Karim SMR, Ismail BS. Kawalan rumpai dalam tanaman padi tabur terus: Suatu tinjaun (Effects of weeds in direct-seeded rice: $A$ review). Buletin Teknol Tanaman Bil. 2005;2:15-25.

114. IRRI (International Rice Research Institute). Main weeds of rice in Asia; 2003.

115. Radosevich SR, Holt JS, Ghersa CM. Weed Ecology. Implications for Management, $2^{\text {nd }}$ ed. New York: Wiley;1997:355.

116. Chauhan BS, Yadav A. Weed management approaches for dry-seeded rice in India: a review. Indian Journal of Weed Science 2013;45(1):1-6.

117. Yadav RI, Singh MK, Singh RK. Integrated weed management in dryseeded rice. Indian Journal of Weed Science. 2014;46(2):172-173.

118. Singh VP, Singh G, Singh RK. Effect of weed management and crop establishment methods on weed dynamics and grain yield of rice. Indian Journal of Weed Science. 2005a;37:188-192.

119. Singh VP, Govindra Singh, Singh RK. Integrated weed management in direct seeded spring sown rice under rainfed low valley situation of Uttaranchal. Indian Journal of Weed Science. 2001;33:63-66.

120. Sardana V, Mahajan G, Grar AS. Agronomic manipulations for higher productivity of direct seeded rice (Oryza sativa L.). Haryana Journal of Agronomy. 2004;20(1/2):71-74.

121. Maity SK, Mukherjee PK. Integrated weed management practices in dry direct-seeded summer rice (Oryza sativa). Indian Journal of Agricultural sciences. 2009;79(12)

122. Angiras NN, Sharma V. Integrated weed management studies in direct seeded upland rice (Oryza sativa). Indian Journal of Weed Science. 1998;30:32-35.

123. Singh RP, Singh CM, Singh AK. Effect of crop establishment methods, weed management and split nitrogen application on weeds and yield of rice. Indian Journal of Agricultural Sciences. 2005;75(5):285-287.

124. Sharma AR. Effect of integrated weed management and nitrogen fertilization on the performance of rice under flood-prone lowland conditions. Journal of Agricultural Science. 1997;129(4):409-418.

125. Balasubramanian V, Ladha JK, Gupta RK. Technical options for rice in the rice-wheat system in South Asia. In: Ladha JK, et al. editors. Improving the Productivity and Sustainability of Rice-Wheat Systems. Issues and Impacts. ASA Special Publication No. 65. American Society of Agronomy, Crop Science Society of America, Soil Science Society of America, USA;2003:115-147.

126. Borrell A, Garside A, Fukai S. Improving efficiency of water use for irrigated rice in a semi-arid tropical environment. Field Crops Research. 1997;52(3):231-248
127. Bouman BAM, Tuong TP. Field water management to save water and increase its productivity in irrigated rice. Agricultural and Water Management. 2001;49(1):11-30.

128. Chauhan BS, Singh VP, Kumar A, et al. Relations of rice seeding rates to crop and weed growth in aerobic rice. Field Crops Research. 2011;121(1):105-115.

129. Gupta RK, Ladha JK, Singh S. Production Technology for Direct Seeded Rice. Rice Wheat Consortium Technical Bulletin 8. New Delhi, India Rice Wheat Consortium for the Indo-Gagetic Plains; 2006:1-16.

130. Kim JK, Kang YS, Lee MH, et al. Wet-seeded rice cultivation technology in korea. In Rice research for food security and poverty alleviation. S. Peng editors. International Rice Research Institute, Los Banos, Philippines. 2001;545-560.

131. Kumar V, Ladha JK, Gathala MK. Direct drill-seeded rice: A need of the day. Pittsburgh. In: Annual Meeting of Agronomy Society of America;2009:1-5.

132. Mahajan G, Ramesha MS, Kaur R. Screening for weed competitivenes in rice - way to sustainable rice production in the face of global climate change. Proceedings of International Conferences on Preparing Agriculture for Climate Change, Ludhiana;2011:6-8.

133. Pandey S, Velasco 1. Economics of direct seeding in Asia: patterns of adoption and research priorities. In: Pandey $\mathrm{S}$ et al, editors. Direct seeding: research strategies and opportunities. Proceedings of the International Workshop on Direct Seeding in Asian Rice Systems, Bangkok, Thailand. Los Baños (Philippines): International Rice Research Institute; 2002:314

134. Riches, Charles R, Orr, et al. Promotion of integrated weed managemen for direct-seeded rice on the Gangetic Plains of India. In: Perspectives on pests II: achievements of research under UK Department for International Development Crop Protection Programme 2000-05. Aylesford, UK Natural Resources International Ltd.; 2006:173-175.

135. Sathyamoorthy NK, Mahendran S, Babu R. Effect of integrated weed management practices on total weed dry weight, nutrient removal of weeds in rice-rice wet seeded system. Journal of Agronomy. 2004;3:263267

136. Sharma RK, Singh R. Furrow irrigated raised bed planting system: an efficient input usage production technology. Indian Farming. 2002;52:25-26.

137. Singh VP, Singh G, Singh SP. Effect of rice wheat establishment methods and weed management in irrigated rice-wheat production system. In: Workshop on Direct Seeded Rice in the Rice-wheat System of the Indo-Gangetic Plains, India. G.B. Pant University of Agriculture \& Technology; 2005: 12 p.

138. Singh, Samar, Bhushan. Weed management in dry-seeded rice (Oryza sativa) cultivated in the furrow-irrigated raised-bed planting system. Crop Protection. 2006;25:487-495.

139. Singh, Samar, Ladha JK, et al. Evalution of mulching, intercropping with Sesbania and herbicide use for weed management in dry-seeded rice (Oryza sativa L.) Crop Protection. 2007;26(4):518-524.

140. Turner FT, Chen CC, McCauley GN. Morphological development of rice seedlings in water at controlled oxygen levels. Agronomy Journal. 1981;73:566-570.

141. Yadav RI, Singh MK, Singh RK. Integrated weed management and crop establishment method for higher yield in direct-seeded rice. Indian Journal of Weed Science. 2014;46(2):166-168. 